\title{
PLC ile Ağırlık ve Sıcaklık Kontrollü Fırın Tasarımı ve Gerçekleștirilmesi
}

\section{Weight and Temperature Controlled Oven Design and Implementation with PLC}

\author{
Adem Gölcük ${ }^{*}{ }^{*}$, Abdulazim Hansu ${ }^{2} \oplus$ \\ ${ }^{1}$ Selçuk Üniversitesi Teknoloji Fakültesi Biyomedikal Mühendisliği Bölümü, Konya, TÜRKIYY \\ ${ }^{2}$ Selçuk Üniversitesi Fen Bilimleri Enstitüsü Mekatronik Mühendisliği Ana Bilim Dalı, Konya, TÜRKIYE \\ Sorumlu Yazar / Corresponding Author*: adem.golcuk@selcuk.edu.tr \\ Geliş Tarihi / Received: 19.12.2020 \\ Araştırma Makalesi/Research Article \\ Kabul Tarihi / Accepted: 26.01.2021 \\ DOI:10.21205/deufmd.2021236901 \\ Atıf șekli/How to cite:GÖLCÜK A.,HANSU A(2021). PLC ile Ağırlık ve Sıcaklık Kontrollü Fırın Tasarımı ve Gerçekleștirilmesi, DEUFMD, \\ 23(69), 713-723.
}

\section{Özet}

Gün geçtikçe enerjinin daha verimli kullanılması amacıyla yüksek enerji verimliliğine sahip ve kullanım kolaylığı sağlayan fırınlar üzerindeki çalışmalar artmaktadır. Günümüzde, elektrikli fırınlarda kontrol yöntemleri geliştirilmekte ve kontrolü sağlamak için kullanılan veriler artmaktadır. Bu çalışmada; elektrikli fırınlarda enerji tüketimi, pişirme süresi, pişirme programları ve pișirme kalitesi gibi özellikleri etkileyen unsurların belirlenmesi amacıyla çșitli makaleler ve patentler incelenmiștir. Bu konuya mühendislik bakış açısı ile yaklaşarak ve pişirilecek olan ürünün ağırlı̆̆ını dikkate alarak sıcaklık kontrolü yapılabilen ve pişirme süresi ayarlanabilen PLC kontrollü, dokunmatik ekranlı elektrikli fırın tasarlanmıştır. Kullanıcı sıcaklık kontrolünü, pişirme süresini ve pişirme programını dokunmatik ekran ile ayarlayabilmektedir. Kullanıcı dokunmatik ekran üzerinden pişme sürecini grafiksel olarak takip edebilmekte ve aynı grafikteki verileri de kayıt altına alabilmektedir. $\mathrm{Bu}$ çalışmada, ekmek hamurunun pişme sürecindeki ağırlığının sıcaklığa göre değişimi incelenmiştir. Aynı ekmek hamurunun farklı gramajları benzer sıcaklıklarda pişirilmiş, pişme süreleri ve ağırlık değişimleri arasındaki farklar karşılaștırılmıștır. Pişirilen hamurun ağırlığı arttıkça, piştikten sonraki gramaj kaybının da arttığı gözlenmiștir.

Anahtar Kelimeler: PLC, Akıllı Fırın, Pișirme Programı, Pișirme Süresi, Ağırlık Kaybı

\begin{abstract}
Day by day, studies on electric ovens with high energy efficiency and ease of use are increasing in order to use energy more efficiently. Nowadays, control methods are being developed in electric ovens and the data used to control them are increasing. In this study; Various articles and patents have been examined in order to determine the factors affecting properties such as energy consumption, cooking time, cooking programs and cooking quality in electric ovens. Approaching this subject with an engineering perspective and taking into account the weight of the product to be cooked, a PLC controlled, touch screen electric oven has been designed, which can be temperature controlled and the cooking time can be adjusted. The user can adjust the temperature control, cooking time and cooking program with the touch screen. The user can follow the cooking process graphically on the touch screen and record the data in the same graphic. In this study, the change in
\end{abstract}


the weight of bread dough in the baking process according to the temperature was examined. Different weights of the same bread dough were baked at similar temperatures, and the differences between baking times and weight changes were compared. It was observed that as the weight of the cooked dough increased, the weight loss after cooking also increased.

Keywords: PLC, Intelligent Oven, Cooking Program, Cooking Time, Weight Loss

\section{Giriş}

Fırınlarda pișirme işlemi yıllardır yapılmakta ve teknolojik gelișmelere bağlı olarak yeni nesil firınlar üretilmektedir. Günümüzde kullanılan cihazların birçoğu program ara yüzleri sayesinde kullanıcıya göre șekil almakta, kullanıcı basit bir şekilde özgün kullanım yapabilmektedir. Örneğin; kullanıcı sıcaklık düğmesini çevirmek yerine dokunmatik ekran aracılığıyla sıcaklığı, süreyi, gıda çeşidini, pişirme programını ayarlayabilmektedir. Haberleșme teknolojilerinin gelișimiyle birlikte birçok cihazda uzaktan haberleşme de sağlanabilmektedir[1].

Akıllı fırın tasarımı ve PLC ile gerçekleștirilmesi konusunda teknolojik gelişmeler araştırılmış, yapılan çalışmalar incelenmiş olup genelde pişirme programlamasında gıda türüne göre programlamaya gidildiği sonucuna varılmıștır. Pişirme işlemine başlanılacağında gıda türü olarak balık, et, tavuk, pizza gibi otomatik sınıflandırmalar yapıldığı görülmüștür. Kullanıcı otomatik pișirme yapabileceği gibi pişirme işlemini program seçimi yapmadan basit bir şekilde sıcaklık ve süreyi seçerek de yapabilmektedir. Bazı firınlarda, derin dondurucudan çıkarılan donmuş gıdalar için donmuş halden pişirmeye hazır hale gelene kadar ön ısıtma programları yer aldığı görülmüştür. Fırınlarla ilgili araștırmalarda, gıdanın ağırlığı dikkate alınarak yapılmış fazla bir çalışmaya rastlanılmamıştır[1].

Programlamanın yanı sıra gıda ağırlığının pişme sürecine etkisinin de göz önüne alındığı kullanıcının kolayca kendine uyarlayabildiği bir fırın tasarımı ve araștırması ihtiyacı doğmuștur. Bu sebeple yapılan çalışmada dokunmatik ekran kullanılarak ağırlık faktörlü program seçimi oluşturulabilecek bir tasarım yapılmıștır[1].

Gerçekleştirilen tasarımda, güncel teknoloji kullanılarak üretilen firınlarda bulunan özelliklere ilave olarak ağırlık kontrollü program oluşturulabilen, özgün bir şekilde adlandırılabilen ve süre-sıcaklık eğrisi izlenip istenildiğinde pişirme verileri kaydedilen bir sistem tasarlanmış ve gerçekleştirilmiştir. Bu konuda PLC'nin avantajları da kullanılarak programlama ișlemi yapılmış ve ağırlığa göre pişirme sürecini gözlemleme amaçlı örnek uygulama yapılmıștır. Çalıșmada, basit ev tipi firın kullanılarak tasarlanan sisteme uygun olması amaciyla firının sadece rezistans ve gövde kısmı kullanılıp diğer kısımları devre dıșı bırakılmıştır. Tasarlanan sistemde, fırında pişirme işlemini kontrol ve kumanda etmek için PLC modülü, sıcaklık modülü ve güç kaynağı kullanılmıştır[1].

Ekmek yapımında, pişirme sırasında ısı ve su taşınımı üzerine bir çalışma yapılmıştır. Ekmek somunları firında $225{ }^{\circ} \mathrm{C}$ 'de, 35 dakika süreyle pişirilmiştir. Buğday unu ile pişirilen ekmeğin pişirme sırasındaki sıcaklığı ölçülmüştür. Sonuçlar, yapısal bir değişikliğin gerçekleştiği $70 \pm 5^{\circ} \mathrm{C}$ 'ye kadar merkezdeki su içeriğinin çok az değiștiğini göstermiștir. Bu sonuçlara göre bu sıcaklığa ulaştıktan sonra somun merkezindeki su içeriği, ılık bölgelerden buhar taşınımı nedeniyle arttığı gözlemlenmiştir. Somun içindeki suyun geometrik merkeze değil de en soğuk bölgeye doğru hareket ettiği gözlemlenmiştir[2]. Ekmek hamurunun pișirilmesi esnasında kabuk ve iç arasında gerçekleşen yaklaşık $100^{\circ} \mathrm{C}$ 'deki buharlaşmanın etkisiyle sıcaklık ve nem içeriğindeki değişmelerin tanımlandığı fenomenolojik bir model geliştirilmiştir. Buharlaşma sayesinde ürün içerisinde iç ve kabuk olmak üzere iki farklı bölge oluştuğunu tespit edilmiştir. Kabuktaki nem miktarının çok düşük olduğu ve kabuktaki sıcaklığın firın sıcaklığına çok yakın olduğu tespit edilmiştir. İç bölgede ise nem miktarı sabit olup sıcaklığın da yaklaşık $100^{\circ} \mathrm{C}$ olduğu gözlenmiştir[3]. Kontrol uygulamalarında tercih edilen kontrolör olan PID (Proportional İntegral Derivative) kullanılarak sıcaklığın denetimi incelenmiștir. Sıcaklık denetimi konusunda PID yöntemi kullanılması ve PID parametreleri üzerine birçok uygulama gerçekleştirilmiştir[4]. Ev tipi elektrikli firınlarda pișirme performansını artırmak için hava dağıtım kanalı tasarlamıştır. Fırın performansının belirlenmesinde enerji tüketimi ve pişirme kalitesinin önemine binaen 
literatür araştırmaları yapılmıștır. Hava dağıtım kanalının pișirme performansındaki önemini fark etmiş ve hava dağıtım kanalı tasarlama aşamalarıyla ilgili de araştırmalarda bulunmuştur. Yapılan araștırmalar sonucu fırın içi sıcaklık dağılımını da dikkate alarak deneyler yapılmıştır. Kullanılan programlar sayesinde elde edilen sayısal verilerle nihai hava dağıtım kanalı tasarımı olușturulmuștur. Bu tasarımdan faydalanılarak bir prototip hazırlanmış ve bu prototiple fırın içi sıcaklık ölçümü de yapılarak sayısal veriler elde edilmiștir. Elde edilen bu sayısal veriler kullanılarak pişirme deneyleri yapılmıștır. Pișirme süresi, sıcaklık dağılımı ve pişme kalitesi karşılaștırılmıştır. Deney sonuçları ile sayısal çözüm sonuçları karşılaștırıldığında, toplam debide \%15,1 fark bulunduğu görülmüştür[5]. PLC kullanarak olușturulan otomatik ekmek üretim hattı, yoğurma kısmından pişirme kısmına kadar olan süreci kapsamaktadır. Bu süreç üç aşamada değerlendirilmiștir. $\mathrm{Bu}$ așamalar hamur yoğurma, hamur şekil alma ve son olarak da pișirme așamasıdır. Bu așamaları yaklașık 100 adet giriş, çıkış sayısına sahip üç adet PLC üzerinden kontrol etmișlerdir. Haberleșme için RS232 protokolü kullanılmıştır. $\mathrm{Bu}$ sayede ekmek üretim hattındaki birçok karmaşıklık PLC sayesinde basit bir șekilde çözülmüștür. Üretim hatlarında meydana gelen arızalar azalmıştır. Çalışan işçi sayısı azalmış, yakıt tüketimi düşmüș, ekmek maliyeti düşmüș, kalite artmış ve hijyen sağlanmıştır [6]. Prototip olarak bir seramik fırın tasarlamıșlardır. Sıcaklık kontrolünü karşılaştırmak için değişken modlu bir kontrolör uygulaması kullanılmıştır. Yapılan karşılaștırmalar ve deneyler sonrasında PID kontrolünün daha verimli olduğu düșünülmektedir[7]. Ekmek hamuru tasarımı için farklı çavdar unları kullanılmıș ve 8 farklı hamur elde edilmiștir. Elde edilen bu hamurlar Farinograf, Ekstensograf ve Amylograf cihazlarını kullanarak karşılaștırılmıștır. Elde edilen ekmeğin kalitesinde kullanılan çavdar oranının değișiklik olușturduğu sonucuna varılmıștır. Çavdar oranı aynı zamanda ekmeğin hacmini de etkilemiştir. Yapılan deneyler sonucu çavdar unu oranının; ekmek içi rengini, kabuk rengini, dokusunu, elastikiyetini ve tadını etkilediği sonucuna varılmıştır [8]. PID denetleyicilerin yapısı, tasarımı ve uygulaması araştırılmış ve çift cidarlı (ceketli) reaktör tank ısıtma sistemi tasarlanmıștır. Yapılan bu tasarımda PID yöntemiyle PLC kullanılarak kontrol ve kumanda işlemi sağlanmıștır. $\mathrm{Bu}$ tasarım gerçekleștirilirken kontrol sistemleri ve çeşitli denetleyiciler araştırılmıştır[9]. Demirçelik ve gıda üretimi sahalarında endüstriyel fırınların kullanılmasından faydalanılarak geniş bir araştırma gerçekleştirilmiştir. Elektrikli firınların sıklıkla tercih edilmesinin nedeni birçok avantaja sahip olmasıdır. Bu avantajlar; çevreci, güvenli, ucuz olması ve depo edilmesine gerek olmamasıdır. $\mathrm{Bu}$ avantajlarla birlikte elektrikli firınlarda sıcaklık kontrolünün de daha kolay olduğu sonucuna varılmıștır. $\mathrm{Bu}$ araștırmalar değerlendirilerek PLC sayesinde kontrol sağlanan bir SCADA sistemi gerçekleştirilmiştir. Gerçekleștirilen bu sistem fırının sıcaklığını kontrol etmek için kullanılmıștır. Fırının sıcaklığını uzaktan kontrol ve kumanda etmek amaciyla operatör panel kullanılmıștır. Sicaklık, sensörler yardımıyla anlık ölçülerek istenen değerle karşılaştırılmış ve en kısa sürede istenen sıcaklığı sağlamak için firın gerilimi analog olarak kontrol edilmiştir[10]. Günümüz teknoloji ve biliminin çok hızlı bir șekilde gelişmesi sonucu ihtiyaçların da aynı oranda artmasından dolayı hızlı, kaliteli ve güvenli üretim sistemlerinin önemine dikkat çekilmiştir. Bu konuda, PLC ve SCADA sistemleri sayesinde kolay, kaliteli ve hızlı bir șekilde üretim sağlandığı yapılan araștırmalar sonucu elde edilmiștir. Prototip bir endüstriyel sistem üzerinde PLC kontrollü bir SCADA sistemi tasarlanmıştır. Tasarlanan sistem uzaktan kumanda edilerek basınç, ağırlık, seviye, sicaklık ve debi gibi değișkenler kontrol edilmiștir[11]. Mevcut firınlarda kontrol isıtıcı elemanın sıcaklığına veya fırının içerisindeki havanın sıcaklığına göre yapılmaktadır. Pişme sırasında, ıșınımla ısı transferinin önemli olduğu tespit edilmiștir. Ișınımla ısı transferi, kondüksiyon durumunda konveksiyona göre daha etkili olmaktadır. Konveksiyon ile pişirme yapılması durumunda toplam isı akısının pișirilen ekmeğin farklı yüzeylerine homojen olarak dağıtılamadığı gözlemlenmiștir. Gerçekte, alt ve üst ısı akısı arasında \%50 fark oluşması fırınlarda pişirme kalitesi açısından olumlu değildir. Kontrol stratejisi olarak sıcaklık ölçümlerine dayanan geleneksel kontrol stratejilerinin yerine isı akısına dayanan yaklaşım kullanılmalıdır[12, 13]. 


\section{Materyal ve Metot}

Bu çalışmada evlerde kullanılan firının kontrolü için PLC'li bir sistem tasarlanmıştır. Pişirme programı ve pișme süresi gibi ayarları kullanıcı dokunmatik panel üzerinden yapmaktadır. Sensörlerden gelen tüm veriler PLC'de işlenmekte ve dokunmatik ekran üzerinden bu veriler takip edilmektedir. Sensörlerden gelen bilgiler ile kullanıcının ayarladığ değerler, PLC'ye yüklenen program ile kontrol edilmektedir. Kontrol için gerekli bilgiler çıkış birimi olan rezistans kontrolüne aktarılmıştır[1].

$\mathrm{Bu}$ çalışmada gerçekleştirilen akıllı firın ve tasarımıyla ilgili blok diyagram Şekil 1'de yer verilmiștir. Blok diyagramda; akıllı firın tasarımında kullanılan PLC modülü, sıcaklık modülü, güç kaynağı ve diğer bileșenler gösterilmiştir.

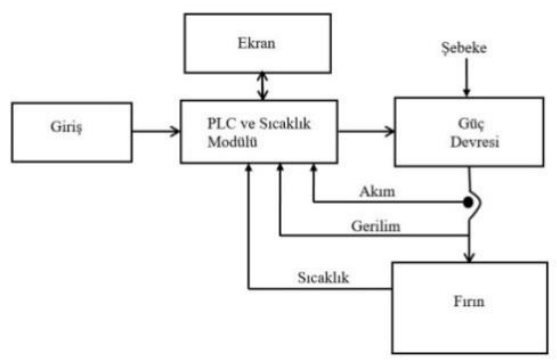

Şekil 1. Tasarlanan sistemin blok diyagramı[1]

Bu blok şemada da görüldüğü üzere akıllı fırının kontrolü PLC ile gerçekleştirilmektedir. Dokunmatik ekran üzerinden kullanıcı fırının kontrolünü sağlamaktadır. Fırının içerisindeki sıcaklığı ölçmek için kullandığımız PT 1000 sıcaklık sensörü kullanılmıștır. PT 1000 sıcaklık sensörünün ürettiği değerler DTC 1000 sıcaklık modülüne iletilir. Sıcaklık modülünden gelen bu değerler PLC tarafından okunup değerlendirilir. Akım ve gerilim değerleri ise PLC modülü ile anlık kontrol edilerek geri dönüşleri alınır.

\subsection{Programlanabilir Mantıksal Denetleyici (PLC)}

"Programmable Logic Controller" kelimelerinin baş harflerinin birleşiminden PLC kısaltması oluşturulmuştur. PLC'ler, EEPROM programlayıcılar ve PIC ișlemciler kullanılarak oluşturulmaktadır. PLC sistemlerinde, gelişmiş otomatik kumanda aygitları kullanılır. Bu aygıtların kontrolü PLC tarafindan her bir aygıta bir adres tanımlanarak sağlanır. PLC'ye bu aygitlardan herhangi biriyle ilgili komut verildiğinde verilen komuta göre kontrolü istenen lamba, kontaktör, motor veya röle gibi çıkışına bağlanan elemanları aktif hale getirmektedir. PLC'de yazılan programda süre kontrolü varsa veya herhangi bir hesap işlemi sonucunda elemanlarla ilgili veri kontrolü varsa PLC bu işlemleri matematiksel hesaplamalar yaparak gerçekleştirebilmektedir [14].

PLC, sistemi kontrol ettiği sahada olușan fiziksel olayları, kontrol edilmek istenen durumları ve hareketleri çeşitli ölçüm cihazları veya sensörler ile belirlemektedir. Sensörler üzerinden modüller aracılığıyla gelen bilgileri, belleğindeki programa göre değerlendirmeye tabi tutar. Mantıksal işlemler yaparak ve verileri değerlendirip ortaya çıkan sonuçları kumanda ettiği elemanlara çlkış sinyali olarak yansıtır. Sahadan gelen veriler, meydana gelen olayların elektriksel sinyallere dönüșmüș halidir. $\mathrm{Bu}$ veriler analog ya da dijital olabilir. Gelen veri analog ise gelen değerin sistemde kodlanan değerleri için sorgulama yapılabilir. Dijital bir veri geldiğinde ise sinyalin özelliğine göre sorgulama yapılabilir. $\mathrm{Bu}$ değerlendirme olayları giriş kartları ile müdahale olayları da çıkış kartları ile yapılmaktadır [15].

PLC kullanılarak gerçekleștirilen sistemlerde meydana gelen hatalar program kontrol edilerek ivedi bir şekilde düzeltilebilir. Üretim tesisleri için hazırlanmış olan PLC'ler, sayısal kodlamalarına göre kontrol ișlemini yaparlar. Bellek birimlerini kullanarak program üzerinde gerçekleștirilen düzeltmeleri ve eklemeleri, PLC hızına göre anlık ișleyip sisteme aktarırlar. Bellek özelliğini kullanarak yapılan bu işlem PLC'nin üretim sistemlerinde tercih edilmesindeki temel sebeplerden biridir [16].

Gerçekleștirilen sistemde kullanılan PLC, DELTA-DVP14SS211R / 8DI-6DO AC/DC Röle SS Serisi'dir. Kullanılan delta PLC; 8 dijital giriș, 6 dijital çıkış ve $24 \mathrm{~V}$ DC beslemeye sahip röle çıkışlıdır. Şekil 3.7'de kullanılan PLC'nin; girişleri, çıkışları ve genel şekli görülmektedir. 


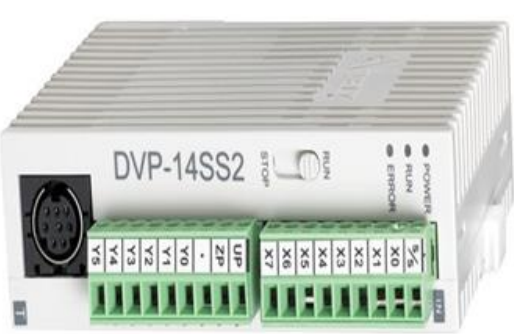

Şekil 2. Tasarlanan sistemde kullanılan röle çıkışlı PLC[17]

PLC'nin bilgisayar ve dokunmatik ekranla olan bağlantıları RS-232 ve RS-485 portları kullanılarak sağlanmıștır. $\mathrm{Bu}$ bağlantılarla alakalı örnek bir diyagram Şekil 3'de görülmektedir.

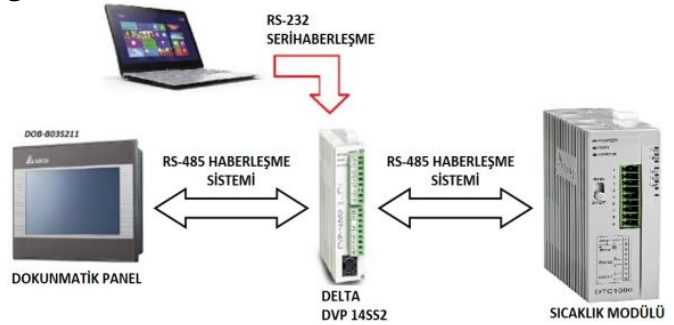

Şekil 3. PLC'nin bilgisayar ve dokunmatik ekranla haberleşme bağlantıları[1]

PLC, ISPSOFT V3.02 programı kullanılarak programlanmıştır. Programlama aşamasında merdiven diyagramı olan Ladder ve fonksiyon blok diyagramı olan FBD kullanılmıştır. Programlama așamasında, modüller ve dokunmatik ekran da göz önüne alınmıştır. Bu sayede ekrandan kontrolü de kolaylaştıracak şekilde gruplandırmalar yapılarak programlar yazılmıştır. Örneğin; pişirilecek gıda manuel olarak pişirilmek isteniyorsa bunun için manuel olarak adlandırılan alt program kullanılmaktadır. Detaylı bir șekilde hazırlanan alt programlar sayesinde manuel veya otomatik pişirme seçenekleri ekrandan seçilerek kullanıcı o ekrana gitmektedir.

Fırındaki ürünün pişirilmesini programlayabilmek için altı adet blok şeklinde grup program hazırlanmıştır. Bu blok şekiller amacına yönelik olarak adlandırılmıştır. Bu blok programlar;

- $\quad$ Main (temel) program

- Manuel program

- Otomatik program

- Reçete programı
- Alarm programı

- Grafik programı

şeklinde adlandırılmıştır. Bu programlardan; Main (temel) program, genel işleyişle alakalı ana programı olușturmaktadır. Manuel olan program; pişirilecek olan gıdanın sıcaklık, süre gibi değerlerini manuel olarak kontrol etmektedir. Otomatik olan programda, kullanıcı sistemde kayıtlı olan herhangi bir programı seçebilmektedir. Reçete programı kullanılarak kaydedilen programlar ile kullanıcı; kayıtlı olan programı seçtiğinde, bellekteki kayıtlı bilgilere göre pişirme işlemi gerçekleşmekte veya kullanıcı önceden test ettiği süre, sıcaklık ve ağırlık bilgilerini girerek bir program oluşturabilmekte ve bunu otomatik olarak çalıştırabilmektedir.

\subsection{Sıcaklık Kontrol Modülü}

Tasarlanan sistemde kullanılan sıcaklık kontrol modülü, PLC ve PT1000 sıcaklık modülleriyle bağlantılıdır. Sıcaklık kontrol modülü; fırının iç kısmındaki sıcaklığı homojen olarak ölçmeyi sağlayan PT1000 sıcaklık sensörünün ürettiği değeri okur ve PLC'ye iletir. PLC'nin okumuş olduğu bu sıcaklık değeri dokunmatik ekranda santigrat derece $\left({ }^{\circ} \mathrm{C}\right)$ olarak gösterilir. Tasarlanan sistemde kullanılan sıcaklık kontrol modülü; Delta-DTC1000R, Röle + Röle çıkışlıdır. Sistemde kullanılan sıcaklık kontrol modülünün örneği Șekil 4'de görülmektedir.

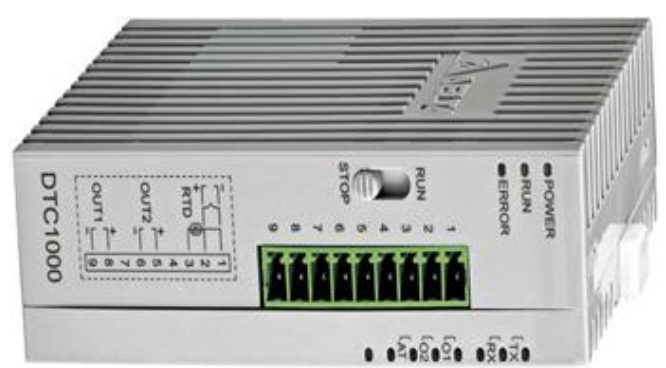

Şekil 4. Sıcaklık kontrol modülü[18]

Sıcaklık kontrol modülü, PT1000 sıcaklık sensörü tarafından kendisine gelen direnç değerini dijital sinyale dönüştürerek çalışır. Dönüştürme işleminden sonra PLC'ye anlık olarak sıcaklık değerini ileterek kullanıcının sıcaklığı anlık olarak takip etmesine imkân sağlar. 


\subsection{Sicaklık Sensörü}

Tasarlanan sistemde kullanılan sıcaklık sensörü PT1000'dir. Bu sensörün öz direnci ısı değerine göre değişkenlik gösteren elektronik devre elemanıdır. Sıcaklık ölçümünü yapabilmek için üretilmiş olan, ortam sicaklığı değiștiğinde değeri değișen bir tür dirençtir. Sıcaklık değerine bağlı olarak PT1000'in ürettiği direnç, Callendar-Van Dusen denklemi ile hesaplanabilmektedir. Sicaklık-direnç değişimleri arasında aşağıdaki formülle belirtilen bir ilişki vardır[19, 20]

$\mathrm{R}_{\mathrm{t}}=\mathrm{R}_{0}\left(1+\mathrm{At}+\mathrm{Bt}^{2}\right)$

$\mathrm{R}_{0}=0{ }^{\circ} \mathrm{C}^{\prime}$ deki direnç $\left(0^{\circ} \mathrm{C}^{\prime}\right.$ de $\pm 0.1 \mathrm{ohm}$ toleransla $1000 \mathrm{ohm}$ )

$\mathrm{R}_{\mathrm{t}}=$ Herhangi bir $\mathrm{T}$ sıcaklığındaki direnç $\mathrm{t}=$ Sicaklık $\left({ }^{\circ} \mathrm{C}\right)$

$\mathrm{A}=0390784 \times 10-2 \mathrm{C}-1$ (sabit)

$\mathrm{B}=0.578408 \times 10-6 \mathrm{C}-2$ (sabit).

$\mathrm{Bu}$ formüle göre sıcaklıktaki her $1{ }^{\circ} \mathrm{C}$ artış, direnç değerinde ortalama 3.84 ohm'luk bir artış demektir. PT1000, tür olarak bir termodirençtir. Termodirençler RTD (Rezistans Termo Direnç) olarak adlandırılırlar. Termodirençlerin kullanıldıkları sıcaklık ölçüm aralığı 80 ile $600{ }^{\circ} C^{\prime}$ dir. Termodirençler ısındıkça çıkıș sinyalindeki direnç değeri parabolik olarak artar. Endüstriyel alanda ve sanayide farklı tiplerde RTD'ler üretilir.

Kullanılan sıcaklık sensörü fırının orta noktasına yerleștirilerek daha hassas bir sıcaklık ölçümü yapılması amaçlanmıştır. $\mathrm{Bu}$ sayede fırın içi sıcaklığı ortalama bir değer olarak elde edilmiştir. PT1000 sicaklık sensörünün ürettiği direnç değeri PLC'ye aktarılırken PLC ile uyumlu olarak seçilen sıcaklık kontrol modülünde işlenmektedir. Sistemdeki sıcaklık ölçümü anlık olarak PLC'ye iletilmektedir. Fırın içi oluşturulmak istenilen sıcaklık değeri, dokunmatik ekran üzerinden veya program üzerinden girilerek sağlanmaktadır.

\subsection{Dokunmatik Ekran}

Tasarlanan sistemde kullanılan dokunmatik ekran; Delta DOPB03S211, TFT (Thin Film Transistör), 4.3 inç, 65536 renk (480x272 pixels) operatör paneldir. Kullanılan bu dokunmatik ekran, sistemdeki PLC ile uyumlu ve bağlantılıdır. $\mathrm{Bu}$ sayede dokunmatik ekran üzerinden sistem kontrol edilebilmektedir.
Kontrol ișlemi esnasında yapılan pișirme işlemini grafiksel olarak anlık izleme imkânı ve kayıt altına alma imkânı da sunmaktadır. Dokunmatik ekranın teknik özellikleri[21]:

- $\quad$ ARM 32-bit RISC ișlemci

- Tüm delta ürünleriyle haberleșebilmesinin yanı sıra tanınmış birçok kontrol cihazıyla da haberleşebilme

- USB, COM1(RS232), COM2\&COM3 (RS-485/RS-422/RS-232)

- USB\&RS-232 güncelleme ve indirme

- 65536 renk TFT LCD

- LED arka ışık

- Programlamada 8 ayrı dil seçeneği

- Üç ayrı porttan aynı anda farklı kontrol cihazlarıyla haberleșebilme

- Reçete güncelleme ve indirme

- Online/Offline simülasyon

- Ekran koruyucu tanımlayabilme

- Takvim ve gerçek zaman saati

- Yardımcı fonksiyon tuşları

- Kullanıcı dostu ekran yazılımı

şeklinde sıralanabilir. Dokunmatik ekranı programlamak için Delta IA HMI DOPSOFT adlı program kullanılmıştır. Dokunmatik ekran programlanırken kullanıcının kolay bir şekilde müdahale edebilmesi hedeflenerek programlama yapılmıștır. $\mathrm{Bu}$ amaca binaen kontrol ekranları olușturulmuștur. Program çalıştırılıp ana sayfa açıldığında, Şekil 5'deki ekran gelmektedir.

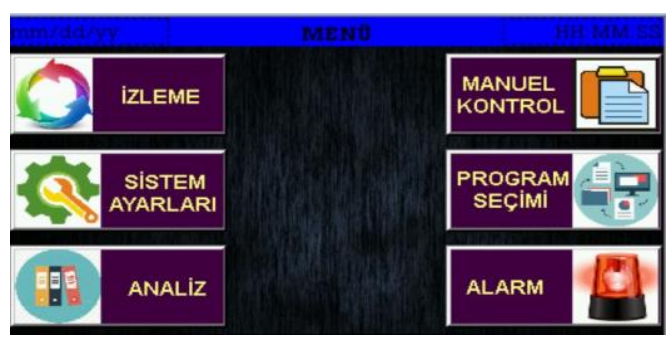

Şekil 5. DOPSOFT ana ekran[1]

Ana ekranda; izleme, manuel kontrol, sistem ayarları, program seçimi, analiz ve alarm olmak üzere seçenekler mevcuttur. Yapılacak işleme göre bu seçeneklerden herhangi biri seçilebilir. İzleme işlevi seçildiğinde 1. Pişirme İşlemi Başlat, 2. Ön Hazırlama Başlat, 3. El İşareti, 4. Ana Sayfa ve 5. Program Seçimi komutlarından herhangi biri seçilebilir. Bu ekranda aynı zamanda fırının o andaki sıcaklık değeri, istenen 
sıcaklık değeri ve istenen sıcaklık değerine kalan fark derece cinsinden sayısal değer olarak görülebilir.

İzleme butonu altındaki "Ön Hazırlama Başlat" komutu seçildiğinde, firın pişirilecek olan gidayı ön hazırlık sıcaklığına getirir ve o sıcaklıkta bırakır. $\mathrm{Bu}$ sayede gıda, pişirilmesi istenen sıcaklığa hazır bir hale getirilerek firında pișirilebilir. Gıda pișene kadar geçen süre, kullanıcıya göre şekillendirilebilir. Bu komut, genelde donmuş gidalar için tercih edilmekte olup gıdanın çözülmesini sağlar ve pişme işlemine hazır hale getirir.

"Pişirme İșlemi Başlat" komutu seçildiğinde, sisteme kaç derece sıcaklıkta ve ne kadar süre pişirme işlemi yapılacağı bilgileri girilerek pişirme işlevi gerçekleştirilir. Pişirme esnasındaki sistem verileri dokunmatik ekrandan izlenebilir.

Ekrandaki "El İșareti" seçildiğinde, dokunmatik kalibrasyon işlemi gerçekleştirilir. Bu sayede dokunmatik hassasiyet güncellenmiş olur.

"Program Seçim" komutu kullanılarak sistemde kayıtlı olan programlardan herhangi bir pişirme programı seçilir ve pişirme işlevi gerçekleştirilebilir.

"Ana Sayfa" komutu, açllış ekranına dönüşü sağlar.

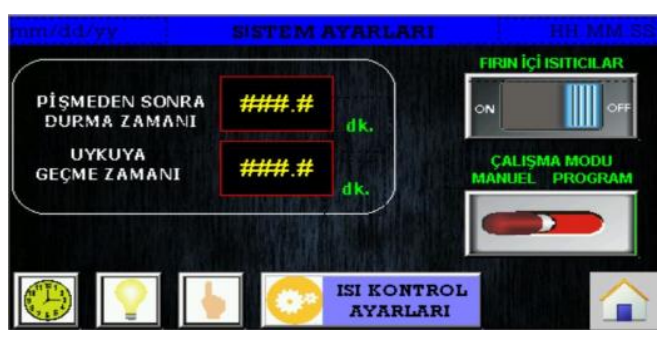

Şekil 6. DOPSOFT ayarlar ekranı[1]

Şekil 6'da görüleceği üzere, ayarlar ekranı seçildiğinde sistemin genel ayarlamaları yapılabilir. Pişme işlemi gerçekleştikten sonra rezistans kontrolü sayesinde pişme işleminden sonra durma zamanı seçilerek rezistans kontrolü üzerinden süre kontrolü yapılabilir. Uykuya geçme zamanı seçilerek kaç dakika boyunca ișlem yapılmadığında ekranın uyku moduna geçeceği seçilebilir. Fırın içi ısıtıcılar bu ekrandan açlk veya kapalı olarak ayarlanabilir. $\mathrm{Bu}$ sayede olası bir program hatası durumunda manuel kontrol sağlanabilir. Saat simgesinden zaman ve tarih ayarları yapılabilir.

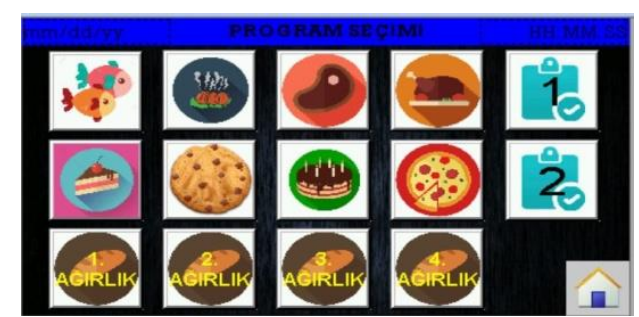

Şekil 7. DOPSOFT program seçimi ekranı[1]

Şekil 7'deki ekran, ana ekrandan "Program Seçimi” komutuna gidildiğinde açllmaktadır. Bu ekrandan pişirilecek gıda türüne göre görsel şekillerden de faydalanılarak seçim yapılabilir. Programda kayıtlı pişirme işlemlerinden herhangi biri gerçekleştirilebilir. Ekrandaki programlar kullanılarak pişirme işlemi gerçekleştirmenin yanı sıra iki adet ilave program seçeneği ve dört adet ağırlığa göre ekmek pişirme programı bulunmaktadır. Görse olarak balık, tavuk, et, pizza, kek, pasta, kurabiye imgeleri ekrana yerleștirilmiștir.

Tasarlanan sistemde, otomatik ve manuel kontrol seçeneklerini geliștirmek için grafik özelliği eklenmiştir. Grafik özelliği kullanılarak pişirilen gıdanın ne kadar sürede, hangi sıcaklık değerlerinde piștiği anlașılmaktadır. Bu grafik, fırının içindeki anlık sıcaklığı zaman ekseninde göstermekte ve pişirme işlemi esnasında sistemdeki bilgileri kullanıcıya sunmaktadır. Bu grafikteki veriler kayıt edilebilmektedir. Bu verilerden yola çıkarak daha kaliteli pişirme işlemi için fikir geliştirilebilir ve çalışmalar yapılabilir. Kullanıcı, yapacağı bu çalışmalar sonrasında kendisine uygun olan pișirme grafiğinden faydalanarak pişirme programlarını kendine özgü bir hale getirebilir.

$\mathrm{Bu}$ çalışmada pişirilecek gıdanın gramajı da pișirme ișlemini etkilediği gözlemlenmiștir. Gıdanın hacmi ve şekli de pişme sürecinde farklılıklar olușturmaktadır. $\mathrm{Bu}$ etkenler düșünülerek hazırlanan otomatik pișirme programlarında, pişirilecek gıdanın ağırlık bilgisinin de kaydedildiği program oluşturabilmesine olanak sunulmuștur.

\section{Uygulama ve Bulgular}

Yapılan uygulama çalışmasında, eşdeğer malzemeler kullanılarak hazırlanan üç farklı ağırlıkta ekmek hamuru kullanılmıștır. Buradaki amaç ağırlığın pișme sürecine etkisini 
incelemek olmuștur. Sekil ve hacim açısından birbirine benzer olmak üzere hazırlanan üç hamurun ağırlıkları sırasıyla; $220 \mathrm{~g}, 440 \mathrm{~g}$ ve $660 \mathrm{~g}$ olarak seçilmiştir. Bu üçlü hamur seti pişirilerek elde edilen veriler kaydedilmiş ve değerlendirilmiştir. Sonrasında; 178 g, 340 g ve $479 \mathrm{~g}$ ağırlıktaki ekmek hamurları hazırlanarak pişirilmiştir. Pişme sürecine ait veriler incelenerek ağırlığın zamana göre değișimi incelenmiștir. Ekmek hamurlarının piştiğindeki ağırlık değișimleri, yüzde olarak hesaplanmış ve pişen hamurun yüzde olarak ne kadar ağırlık kaybına uğradığı tespit edilmiștir. tablodan da anlaşılacağı üzere hamurun ağırlığı arttıkça pişme süresi de artmaktadır.

3.1. Pișme Sürecindeki Ağırlığın Zamana Göre Değişimi

Aynı özellikte 3 farklı ağırlıkta ekmek hamuru hazırlanmıştır. $\mathrm{Bu}$ ekmek hamurlarının ağırlıkları; $178 \mathrm{~g}, 340 \mathrm{~g}$ ve $479 \mathrm{~g}$ olarak seçilmiştir. Akıllı fırın, hazırlanan Loadcell sisteminin üzerine yerleștirilerek hamurun pişme esnasındaki ağırlık değişiminin ölçülmesi ve anlık olarak izlenmesi amaçlanmıştır. Hazırlanan ağırlık ölçümü sisteminde 3 adet

Tablo 1 Ağırlığın Pișirilme süresine olan etkisi[1]

\begin{tabular}{|c|c|c|c|c|}
\hline \multicolumn{3}{|c|}{$220 \mathrm{~g}$} & & \\
\hline & Bitiş & re & & \\
\hline 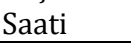 & ti & & & \\
\hline 11.11 & 11.29 & $18 \mathrm{dk}$ & 5 & \\
\hline \multicolumn{5}{|c|}{$\begin{array}{l}\text { Yapılan araştırmalarda ve testlerde, ağırlı̆̆ın } \\
\text { yanı sıra hacmin ve şeklin de pișme sürecinde } \\
\text { etkisi olduğu sonucuna varılmıştır. Hacmin ve } \\
\text { şeklin çok az miktarda olsa da pişme sürecinde } \\
\text { değişiklik oluşturabileceği düșünülerek farkl } \\
\text { ağırlıklarda hazırlanan hamurların, şekil ve } \\
\text { hacim olarak birbirine yakın olmasına önem } \\
\text { verilmiștir. }\end{array}$} \\
\hline \multicolumn{5}{|c|}{ 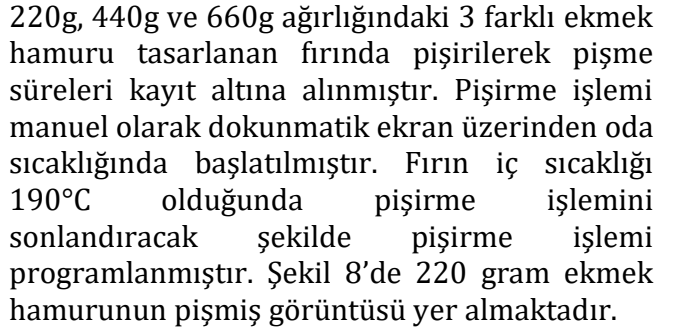 } \\
\hline
\end{tabular}

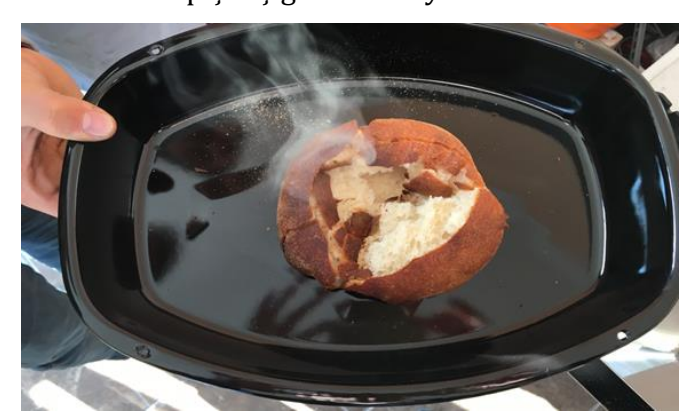

Şekil 8. 220 gram ekmek hamurunun pişmiş görüntüsü[1]

Tablo1'de 220g, 440g ve 660g ağırlığındaki hamurların pişme sürelerini göstermektedir. $\mathrm{Bu}$

\begin{tabular}{|c|c|c|c|c|}
\hline $440 \mathrm{~g}$ & & \multicolumn{3}{|c|}{$660 \mathrm{~g}$} \\
\hline Bitiş & Süre & Başlama & Bitiş & Süre \\
\hline Saati & & Saati & Saati & \\
\hline 12.59 & $24 \mathrm{dk}$ & 11.51 & 12.16 & $25 \mathrm{dk}$ \\
\hline
\end{tabular}

Loadcell kullanılarak ağırlığın belirlenmesi hedeflenmiştir. Loadcell sisteminin üzerine yerleştirilen firınla yapılan pişirme işlemine ait fotoğraf Şekil 9'da görülmektedir. Bu sistem kullanılarak yapılan pişirme işleminde hem anlık sıcaklık değişimi hem de ağırlıktaki değişim ölçülmüştür.

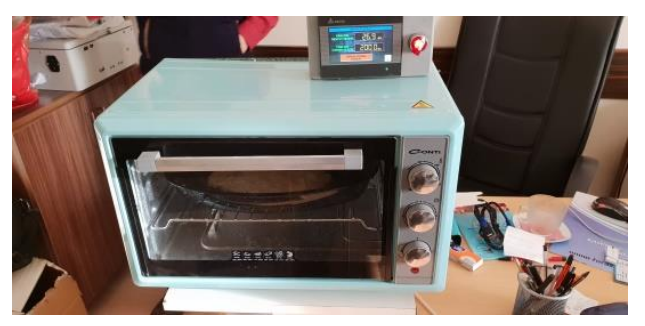

Şekil 9. Loadcell ve akıllı fırın kullanılarak yapılan pişirme işlemi[1]

Şekil 10'da fırındaki pișen gıdanın anlık ağırlık takibini yapabilmek ve veri tabanına kaydedebilmek için hazırlanan C\# yazılımının ekran görüntüsü yer almaktadır. 
DEÜ FMD 23(69), 713-723, 2021

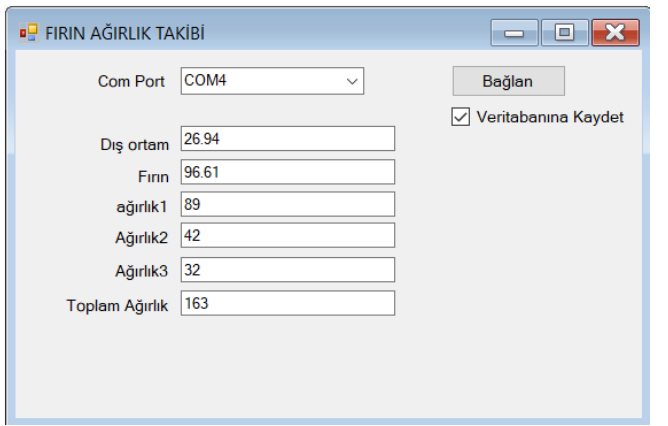

178g, $340 \mathrm{~g}$ ve $479 \mathrm{~g}$ ekmek hamurları için yaptığımız pişirme ișleminde elde edilen veriler Tablo 2, Tablo 3 ve Tablo 4'de verilmektedir. Bu veriler C\#'da hazırlanan yazılım tarafından Access veritabanına kaydedilen verilerdir.

Şekil 10. Fırın ağırlık takibi için hazırlanan C\# yazılımı[1]

Tablo 2. 178g hamurun pișirilme zamanına göre ağırlık değișimi[1]

\begin{tabular}{cccccc}
\hline $\begin{array}{c}\text { Ağırlık 1 } \\
\text { (Loadcel-1) }\end{array}$ & $\begin{array}{c}\text { Ağırlık 2 } \\
\text { (Loadcel-2) }\end{array}$ & $\begin{array}{c}\text { Ağırlık 3 } \\
\text { (Loadcel-3) }\end{array}$ & $\begin{array}{c}\text { Toplam } \\
\text { Ağırlık }\end{array}$ & $\begin{array}{c}\text { Zaman } \\
(\mathrm{dk})\end{array}$ & $\begin{array}{c}\text { Sıcaklık } \\
\left({ }^{0} \mathrm{C}\right)\end{array}$ \\
\hline 85 & 49 & 44 & 178 & Başlangıç & 23.7 \\
85 & 47 & 43 & 175 & 1 & 24.9 \\
87 & 45 & 40 & 172 & 2 & 31.7 \\
87 & 44 & 38 & 169 & 3 & 44.0 \\
88 & 43 & 35 & 166 & 4 & 60.6 \\
90 & 42 & 32 & 164 & 5 & 79.2 \\
90 & 42 & 30 & 162 & 6 & 99.7 \\
89 & 41 & 30 & 160 & 7 & 119.1 \\
90 & 40 & 27 & 157 & 8 & 136.2 \\
91 & 39 & 25 & 155 & 9 & 152.3 \\
94 & 39 & 20 & 153 & 10 & 167.3 \\
94 & 38 & 16 & 148 & 11 & 181.1 \\
95 & 38 & 13 & 146 & 12 & 190.8 \\
94 & 37 & 11 & 142 & 13 & 198.7 \\
95 & 37 & 8 & 140 & 14 & 204.1 \\
90 & 34 & 12 & 136 & 15 & 207.3 \\
\hline
\end{tabular}

Tablo 2'den anlașılacağı üzere, 178 g ekmek hamuru saat $23.7{ }^{\circ} \mathrm{C}$ sicaklıktan itibaren pişirilmeye başlanmıştır. Pişirme işlemi 207.3 ${ }^{\circ} \mathrm{C}$ 'ye kadar sürmüştür. Bu süreçteki ağırlık değişimi de program üzerinden izlenmiștir. Pişirme işlemi başladığında ağırlığı 178 g olarak ölçülmüş olan ekmek hamuru, piștikten sonra 136 g olarak ölçülmüştür. Pişme sürecinde 42g bir ağırlık kaybı oluşmuştur. Yüzde olarak hesaplandığında \%23,6 oranında bir ağırlık kaybı oluşmuştur. Pişme işlemi $15 \mathrm{dk}$. sürmüştür. Tablo 3'den anlaşılacağı üzere, pişirme işlemine başlandığında sıcaklık $33.2{ }^{\circ} \mathrm{C}$ olarak ölçülmüştür. Pişirme işlemi $206.8{ }^{\circ} \mathrm{C}$ 'ye kadar sürmüştür. Pişirme işlemi başladığında ağırlığı 340 g olarak ölçülmüş olan ekmek hamuru, piştikten sonra $294 \mathrm{~g}$ olarak ölçülmüştür. Pișme sürecinde $46 \mathrm{~g}$ bir ağırlık kaybı olușmustur. Yüzde olarak hesap edildiğinde \%13,53 oranında bir ağırlık kaybı oluşmuştur. Pişme işlemi 15 dk. sürmüştür. 
DEÜ FMD 23(69), 713-723, 2021

Tablo 3. 340g hamurun pișirilme zamanına göre ağırlık değișimi[1]

\begin{tabular}{|c|c|c|c|c|c|}
\hline $\begin{array}{c}\text { Ağırlık 1 } \\
\text { (Loadcel-1) }\end{array}$ & $\begin{array}{c}\text { Ağırlık 2 } \\
\text { (Loadcel-2) }\end{array}$ & \multicolumn{2}{|c|}{ Toplam Ağırlık } & $\begin{array}{l}\text { Zaman } \\
(\mathrm{dk})\end{array}$ & $\begin{array}{c}\text { Sicaklık } \\
\left({ }^{0} \mathrm{C}\right) \\
\end{array}$ \\
\hline 110 & 230 & \multicolumn{2}{|c|}{340} & Başlangıç & 33.0 \\
\hline 102 & 229 & \multicolumn{2}{|c|}{331} & 1 & 36.4 \\
\hline 101 & 228 & \multicolumn{2}{|c|}{329} & 2 & 45.7 \\
\hline 99 & 228 & \multicolumn{2}{|c|}{327} & 3 & 63.8 \\
\hline 98 & 228 & \multicolumn{2}{|c|}{326} & 4 & 83.7 \\
\hline 97 & 226 & \multicolumn{2}{|c|}{323} & 5 & 103.7 \\
\hline 96 & 226 & \multicolumn{2}{|c|}{322} & 6 & 121.9 \\
\hline 94 & 226 & \multicolumn{2}{|c|}{320} & 7 & 139.2 \\
\hline 93 & 226 & \multicolumn{2}{|c|}{319} & 8 & 154.2 \\
\hline 89 & 227 & \multicolumn{2}{|c|}{316} & 9 & 167.8 \\
\hline 88 & 225 & \multicolumn{2}{|c|}{313} & 10 & 179.4 \\
\hline 90 & 220 & \multicolumn{2}{|c|}{310} & 11 & 188.9 \\
\hline 90 & 217 & \multicolumn{2}{|c|}{307} & 12 & 196.4 \\
\hline 89 & 214 & \multicolumn{2}{|c|}{303} & 13 & 201.8 \\
\hline 88 & 210 & \multicolumn{2}{|c|}{298} & 14 & 205.2 \\
\hline 87 & 207 & \multicolumn{2}{|c|}{294} & 15 & 206.8 \\
\hline \multicolumn{6}{|c|}{ Tablo 4. 479g hamurun pișirilme zamanına göre ağırlık değișimi[1] } \\
\hline $\begin{array}{c}\text { Ağırlık 1 } \\
\text { (Loadcel-1) }\end{array}$ & $\begin{array}{c}\text { Ağırlık 2 } \\
\text { (Loadcel-2) }\end{array}$ & $\begin{array}{c}\text { Ağırlık 3 } \\
\text { (Loadcel-3) }\end{array}$ & $\begin{array}{l}\text { Toplam } \\
\text { Ağırlık } \\
\end{array}$ & $\begin{array}{c}\text { Zaman } \\
\text { (dk) }\end{array}$ & $\begin{array}{c}\text { Sicaklık } \\
\left({ }^{0} \mathrm{C}\right)\end{array}$ \\
\hline 49 & 156 & 274 & 479 & Başlangıç & 31.1 \\
\hline 47 & 154 & 275 & 476 & 1 & 33 \\
\hline 45 & 154 & 275 & 474 & 2 & 40.2 \\
\hline 43 & 153 & 276 & 472 & 3 & 54.4 \\
\hline 42 & 152 & 275 & 469 & 4 & 74.3 \\
\hline 44 & 151 & 272 & 467 & 5 & 93.9 \\
\hline 41 & 149 & 275 & 465 & 6 & 112.7 \\
\hline 43 & 153 & 266 & 462 & 7 & 129 \\
\hline 43 & 155 & 263 & 461 & 8 & 143.6 \\
\hline 44 & 154 & 261 & 459 & 9 & 157.1 \\
\hline 45 & 152 & 258 & 455 & 10 & 169.4 \\
\hline 44 & 151 & 256 & 451 & 11 & 179 \\
\hline 44 & 150 & 253 & 447 & 12 & 187 \\
\hline 43 & 149 & 252 & 444 & 13 & 193.6 \\
\hline 43 & 147 & 249 & 439 & 14 & 198.1 \\
\hline 42 & 147 & 246 & 435 & 15 & 201.2 \\
\hline 41 & 146 & 243 & 430 & 16 & 203.1 \\
\hline 41 & 145 & 240 & 426 & 17 & 204.4 \\
\hline 40 & 144 & 240 & 424 & 18 & 205.5 \\
\hline $\begin{array}{l}\text { Pişirme işlemi } \\
\text { ekmek hamuru } \\
\text { ölçülmüştür. Pis } \\
\text { oluşmuştur. Yi } \\
\% 11,48 \text { oranın } \\
\text { Pişme işlemi } 18\end{array}$ & $\begin{array}{l}\text { sşladığında ağırlığı } \\
\text { piştikten sonra } 4 \\
\text { he sürecinde } 54 \text { g } \\
\text { de olarak hesap } \\
\text { bir ağırlık kaybı } \\
\text { k sürmüştür. }\end{array}$ & $\begin{array}{l}479 \text { g olan } \\
24 \text { g olarak } \\
\text { ağırlık kaybı } \\
\text { edildiğinde } \\
\text { oluşmuştur. }\end{array}$ & $\begin{array}{l}220 \text { g ekme } \\
\text { verilerinder } \\
\text { dakikada, } 4 \\
\text { programı ve } \\
\text { göre } 24 \quad \text { d } \\
\text { yazdığımız } \\
\text { edilen anlık }\end{array}$ & $\begin{array}{l}\text { hamuru, yazdığ } \\
\text { elde edilen anlı } \\
0 \text { g ekmek hamu } \\
\text { rilerinden elde ec } \\
\text { akikada, } 660 \mathrm{~g} \\
\text { PLC programı } \\
\text { verilere göre } 25\end{array}$ & $\begin{array}{l}\text { PLC programı } \\
\text { ilere göre } 18 \\
\text { azdığımız PLC } \\
\text { anlık verilere } \\
\text { hek hamuru, } \\
\text { erinden elde } \\
\text { ada pișmiștir. }\end{array}$ \\
\hline 4. Tartışma ve & onuç & & Elde edilen & bu verilere gör & sirilecek olan \\
\hline $\begin{array}{l}\text { Tasarlanan } \\
\text { ișlemlerinden } \\
\text { sonuçlar bulunn }\end{array}$ & $\begin{array}{l}\text { stemde yapılan } \\
\text { de edilen veriler } \\
\text { uștur. Bulunan son }\end{array}$ & $\begin{array}{l}\text { pişirme } \\
\text { re göre şu } \\
\text { uçlar; }\end{array}$ & $\begin{array}{l}\text { ekmek har } \\
\text { etkilemekte } \\
\text { doğrusal bir }\end{array}$ & $\begin{array}{l}\text { nurunun ağırlığ } \\
\text { lir. Pişme süresi, } \\
\text { artış göstermemi }\end{array}$ & $\begin{array}{l}\text { me süresini } \\
\text { lajdaki artışla }\end{array}$ \\
\hline
\end{tabular}


Sonrasında yapılan çalıșmada; 178 g, 340 g ve $479 \mathrm{~g}$ ekmek hamurları pișirilmiștir. C\# programında yazdığımız programı kullanarak Loadcell verileriyle anlık ağırlık takibi kontrol edilmiștir. Bu kontrol PLC'deki ekrandan da süreç olarak izlenmiştir. Yapılan bu kontrolde, fırının darasını aldıktan sonra elde edilen hamur ağırlıklarına göre yapılan pişirme işlemine ait bulunan sonuçlar;

- $178 \mathrm{~g}$ ekmek hamuru 15 dakikada pişmiştir. Piștikten sonra 42g'llk bir kayıpla 136g olarak ölçülmüștür. Ekmek hamuru pişme sürecinde $\% 23,6$ oranında bir ağırlık kaybına uğramıștır.

- $\quad 340 \mathrm{~g}$ ekmek hamuru 15 dakikada pişmiștir. Piștikten sonra 46g'lık bir kayıpla 294g olarak ölçülmüștür. Ekmek hamuru pişme sürecinde $\% 13,53$ oranında bir ağırlık kaybına uğramıștır.

- 479 g ekmek hamuru 18 dakikada pişmiștir. Piștikten sonra 55g'llk bir kayıpla 424g olarak ölçülmüștür. Ekmek hamuru pişme sürecinde $\% 11,48$ oranında bir ağırlık kaybına uğramıştır.

$\mathrm{Bu}$ verilerden de anlaşıldığı üzere pișirilen hamurun ağırlığı arttıkça pişen hamurdaki ağırlık kaybı gramaj olarak da artmaktadır.

\section{Teșekkür}

Bu çalışma Selçuk Üniversitesi, Bilimsel Araştırma Projeleri Koordinatörlügü tarafindan 18201061 nolu proje ile desteklenmiştir.

\section{Kaynakça}

[1] A. Hansu, "Ağirliğa Duyarli Sicaklik Kontrollü Firin Tasarimi Ve Gerçekleştirilmesi," Yüksek Lisans Tezi, Konya Teknik Üniversitesi Lisansüstü Eğitim Enstitüsü Elektrik Elektronik Mühendisliği Anabilim Dalı, KONYA TEKNIK ÜNIVERSITESİ, Konya, 2019.

[2] K. Thorvaldsson and C. Skjöldebrand, "Water Diffusion in Bread During Baking," Lwt - Food Science and Technology, vol. 31, pp. 658-663, 1998.

[3] E. Purlis and V. Salvadori, "Bread baking as moving boundary problem. Part 1: Mathematical modelling," Journal of food engineering., vol. 91, pp. 428-433, 2009/04// 2009.

[4] K. J. Astrom and T. Hagglund, "Advanced PID Control," Instrument Society of America, Research Triangle Park, North Carolina/USA., 1995.

[5] M. Kantaş, "Ev tipi elektrikli fırınların performansının sayısal ve deneysel incelenmesi," 2007.

[6] H. Yllmaz and M. Sarıtaș, "Ekmek Üretim Hattında PLC Cihazının Kullanılması."
[7] C. Edwards and S. K. Spurgeon, "Application of Sliding Modes to the Control of Industrial Furnaces. ," Industrial Electronics, Control and Instrumentation, 1994., IECON '94., 20th International Conference, Bologna., 1994.

[8] E. Mankan, "Hamurun fiziksel özelliklerinin cavdar ekmeğinin kalitesi üzerine etkisi," İstanbul Teknik Üniversitesi Fen Bilimleri Enstitüsü, 2008.

[9] M. A. Yersel, "PID Yönteminin PLC'de Yazılarak Gerçeklenmesi: Çift cidarlı reaktör tank sıcaklık kontrolü örneği," 2007.

[10] M. A. S. Usalan, "Bir endüstriyel firın otomasyonu / Automation of an industrial furnace," Fen Bilimleri Enstitüsü, Gazi Üniversitesi, 2015.

[11] A. Özer, "Endüstriyel sistemlerde plc ve scada uygulaması," 2016.

[12] B. Shaughnessy and M. J. A. T. E. Newborough, "Energy performance of a low-emissivity electrically heated oven," vol. 20, pp. 813-830, 2000.

[13] A. Bozgeyik, "Elektrikli Fırınların Enerji Tüketimini Azaltmaya Yönelik Yöntemlerin Deneysel Olarak Etkisinin Araştırılması," Fen Bilimleri Enstitüsü, 2006.

[14] R. Cetin, S7-200 Plc'lerle Otomasyon Temel Seviye. Ankara, Türkiye., 2010.

[15] H. Bayazit, Uygulamalı Plc programlama ve Operatör Panel Konfigürasyonu. İstanbul, Türkiye.: Dora Yayınevi, 2012.

[16] M. Yağımlı and F. Akar, Programlanabilir Lojik Denetleyiciler. İstanbul, Türkiye.: Beta Yayınevi, 2008.

[17] DeltaACDrives.com. (25.01.2021). Delta DVP14SS211R DVP-SS Series PLC. Available: https://deltaacdrives.com/delta-dvp14ss211r-dvpss-series-plc/

[18] DeltaACDrives.com. (25.01.2021). Delta DTC1000R DTC Controller. Available: https://deltaacdrives.com/delta-dtc1000r-dtccontroller/

[19] B. İ. TOKMAK. (2013, 17.12.2020). Sicaklık Ölçüm Enstrümanı Termodirenç Pt100 ve Endüstride Kullanımı. Available: https://www.elektrikport.com/teknikkutuphane/scaklk-olcum-enstruman-termodirencpt100-ve-endustride-kullanm/8506\#ad-image-0

[20] A. W. WIKA. (2014, 17.12.2020). Callendar-Van Dusen equations for the calibration of platinum resistance thermometers. Available: https://www.wikapolska.pl/upload/DS_IN0029_en _co_59667.pdf

[21] Delta. (2012, 25.01.2021). DOP-B Quick Start Kullanım Klavuzu. Available: https://www.deltaacdrives.com/Delta-DOP-BQuick-Start.pdf 